\title{
Total Quality Management Constructs and Employee Performance Measures in Manufacturing Industry
}

\author{
Mohd Khairulnizam Zahari, Norhayati Zakuan*, Mohd Shoki Md Ariff , Muhamad Zameri Mat \\ Saman and Siti Zaleha Omain
}

\begin{abstract}
Total Quality Management (TQM) is a management philosophy and operating approach that aims to consistently exceed the current and future expectations of all stakeholders, based on continuous improvement in all processes, goods and services. TQM is very important to the organization in order for them to survive in the global market. The main objective of this study is to develop a TQM and employee performance model. Authors review updated literature on TQM research organized along two main themes: evolution of TQM considering as a set of practice, and its impacts to employee performance. Two research questions are proposed in order to re-validate TQM constructs: (a) Is the set of practices associated with TQM valid as a whole? (b) What performance measures should be considered to exhibit an effectiveness of its implementation?
\end{abstract}

Keywords - Total Quality Management, Employee Performance, Manufacturing Industry, Malaysia

\section{INTRODUCTION}

$\mathrm{F}$ or several years, Manufacturing companies have been using Total Quality Management (TQM) to manage quality within their organization. The manufacturers realized the importance of taking the customer's needs into account to improve product effectiveness, competitiveness, efficiency, and flexibility (Ahmad and Yusof, 2010). TQM is a process that is used strictly for managing quality. It is important to understand that it must be a continuous way of life and a philosophy of perpetual improvement in everything that is done. To determine the success or failure of the firms in manufacturing industry, quality is the key success factor to survive and sustain in the global market (Mohammad Talha, 2004). The effectiveness of TQM implementation can be seen in Japanese companies. TQM has transformed Japanese companies to be more competitive in the global market to win the market share (Garvin, 1988). Now Japanese products are proven to be the best in quality and can compete with their

Mohd Khairulnizam Zahari is with the School of Business Innovation and Technopreneurship Universiti Malaysia Perlis Perlis, Malaysia

Norhayati Zakuan*, Mohd Shoki Md Ariff and Siti Zaleha Omain are with the Faculty of Management, Universiti Teknologi Malaysia (UTM), Skudai, Johor, Malaysia

Muhamad Zameri Mat Saman is with the Faculty of Mechanical, Universiti Teknologi Malaysia (UTM), Skudai, Johor, Malaysia competitors and survive in this stiff market.

\section{LITERATURE REVIEW}

\section{Critical Success Factors TQM Constructs}

There are numerous study that investigates the critical success factors of TQM practices (Sila, 2007). The previous studies have recognized a common set of critical success factors of TQM. To generate distinct generic constructs, a list of constructs proposed by their corresponding authors in previous works is analysed in Table 1 (Agus \& Hassan, 2011; Fotopoulos \& Psomas, 2010; Gadenne \& Sharma, 2009; Koh \& Low, 2010; Phan, Abdallah, \& Matsui, 2011; Prajogo, Chowdhury, Yeung, \& Cheng, 2012; Raj Kumar Dixit Garg T.K. Garg, 2011; Sadikoglu \& Zehir, 2010; Valmohammadi \& Servati, 2011; Zakuan et al., 2010;).

Based on the previous studies through reviewing and synthesis of TQM literature, the author has identified 7 critical success factors of TQM as follows : (1) Top Management Leadership; (2) Customer focus; (3) Education and Training; (4) Information analysis; (5) Employee empowerment; (6) Human resource development; and (7) Management policies and strategy. Supplier management and process quality management are not chosen because the lack of relevance relationship with the employee performance. Supplier management is more on controlling of procured materials and parts and how the top management will determine the best supplier to provide them the best raw materials. In this process, it is hard to measure the performance of employee because there is less significant in this relationship with TQM practices towards employee performance. The process quality management is more on controlling the process, quality and cost and already discussed together in the top management leadership factor.

i) Top Management Leadership (TML)

Top management leadership is one of the important driving factors in implementing Total Quality Management in the organization. 
TABLE 1 TQM CONSTRUCT FROM VARIOUS AUTHORS (2009-20011)

\begin{tabular}{|c|c|c|c|c|c|c|c|c|c|c|}
\hline DETAILS/AUTHOR & \begin{tabular}{|c|} 
Gaddene \\
and \\
Sharma \\
$(2009)$ \\
\end{tabular} & \begin{tabular}{|c|} 
Fotopout \\
os et \\
al. $(2009$ \\
) \\
\end{tabular} & $\begin{array}{c}\text { Koh and } \\
\text { Low } \\
(2010) \\
\end{array}$ & $\begin{array}{c}\text { Sadikogl } \\
\text { u et.al } \\
(2010) \\
\end{array}$ & $\begin{array}{c}\begin{array}{c}\text { Zakuan } \\
\text { et.al 2010) }\end{array} \\
\end{array}$ & \begin{tabular}{|c|} 
Raj Kumar \\
(2011)
\end{tabular} & \begin{tabular}{|c|} 
Arawati \\
Agus (2011) \\
\end{tabular} & $\begin{array}{c}\text { Changiz } \\
\text { (2011) }\end{array}$ & $\begin{array}{c}\text { Mustafa } \\
\text { Mahel } \\
\text { (2014) } \\
\end{array}$ & $\begin{array}{l}\text { Phan et.al } \\
\text { (2011) }\end{array}$ \\
\hline Top management leadersip & $\mathrm{x}$ & $\mathrm{X}$ & $\mathrm{x}$ & $\mathrm{x}$ & $\mathrm{x}$ & $\mathrm{x}$ & & $\mathrm{x}$ & $\mathrm{X}$ & $\mathrm{x}$ \\
\hline Human Resource developmer & & $\mathrm{X}$ & & $\mathrm{x}$ & $\mathrm{X}$ & & $\mathrm{X}$ & & & $\mathrm{x}$ \\
\hline Supplier Management & & $\mathrm{x}$ & $\mathrm{x}$ & $\mathrm{x}$ & $\mathrm{x}$ & & & $\mathrm{X}$ & $\mathrm{x}$ & $\mathrm{x}$ \\
\hline Customer Focus & & $\mathrm{X}$ & $\mathrm{x}$ & $\mathrm{x}$ & $x$ & $\mathrm{x}$ & & $\mathrm{X}$ & $\mathrm{X}$ & $\mathrm{x}$ \\
\hline Education and Training & $\mathrm{X}$ & $\mathrm{x}$ & & & & $\mathrm{x}$ & & & $\mathrm{x}$ & \\
\hline Continuous Improvement & & & & $\mathrm{x}$ & $\mathrm{x}$ & $\mathrm{x}$ & $\mathrm{X}$ & & $\mathrm{x}$ & \\
\hline Product/service design & & $\mathrm{X}$ & & & & & & & & $\mathrm{x}$ \\
\hline Communication & & & & & & $\mathrm{x}$ & & $\mathrm{x}$ & $\mathrm{x}$ & \\
\hline Work process & & & & $\mathrm{x}$ & & & & & & $\mathrm{x}$ \\
\hline Management Policies and Strates & & & & & $\mathrm{x}$ & & & & & $\mathrm{x}$ \\
\hline Benchmarking & $\mathrm{x}$ & & & & & & $\mathrm{x}$ & & & \\
\hline Recognition and Reward & & & & & & $\mathrm{x}$ & & & & \\
\hline Employee empowerment & $\mathrm{x}$ & & & & & & & $\mathrm{x}$ & & \\
\hline Role of Quality Department & & & & & & & & & $\mathrm{x}$ & \\
\hline Process Quality Management & & $\mathrm{X}$ & $\mathrm{x}$ & & & & $\mathrm{x}$ & $\mathrm{X}$ & $\mathrm{x}$ & \\
\hline \multicolumn{11}{|l|}{ Quality Citizenship } \\
\hline Information Analysis & & & $\mathrm{x}$ & $\mathrm{x}$ & $\mathrm{x}$ & & & & & $\mathrm{x}$ \\
\hline Business/ Quality Result & & & & & & & & & & \\
\hline
\end{tabular}

Good leadership will drive the employees to have higher involvement in the implementation of Total Quality Management process and to maintain the momentum of all employees towards satisfaction of the customers. Leadership addresses the critical role of management and also the key in the continuous quality improvement process (Deming, 1986; Crosby, 1979; Garvin, 1988). Implementing Total Quality Management requires a team efforts headed by the top management. Each person in the organization has the responsibilities and it is important for the entire organization to understand the role of leadership in Total Quality Management to ensure the responsibilities will be delegated more effectively. The top management needs to change their style of leadership to more supportive, systematic, participative and charismatic style to ensure the employee involvement in the Total Quality Management programmes or activities, and empower them to make the decisions and necessary actions towards the process improvement and customer satisfaction (Meyer, 2001).

\section{ii) Customer Focus (CS)}

One of the measurements of the quality is the customer satisfaction. Therefore TQM will help to emphasize the quality in the products and service delivery, thus the customer satisfaction will highly be achieved. The company must realize that, bad or good its products will directly impact the product success and in the end it will impact the customer satisfaction (Khanna et al., 2011). The employees who always deal with the customers need to be well trained so that they can sustain the quality towards their customers. Therefore, effective communication between employees and the customers help to enhance customer satisfaction. The company must understand and fulfill the requirement by the customers and do the customer feedback analysis to measure the performance of the products and customer services (Raj Kumar, 2011).

\section{iii) Education and Training (ET)}

Training presents a prime opportunity to expand the knowledge base of all employees. Training and education will help the employees to perform well in their jobs. A training programme allows the employees to strengthen the skills and knowledge that each employee needs to improve. A development programme and effective training will bring all employees to a higher level so they will have similar skills and knowledge (Wruck et al., 1998). Education and training increases the employees working abilities and experiences, decrease the errors, enhance the knowledge and work skills, improve the teamwork and overcome the turnover rate (Kaynak and Hartley, 2008). When employees are helped to improve themselves, the organization will earn the benefits.

\section{iv) Information Analysis (IA)}

Information and analysis refer to the availability of information systems and the procedure and system that provide accurate and timely information for managers to make decision (Flynn et al., 1994). To achieve its objective and to react to any external changes, organization should measure, analysis, review and discuss data on business performance (Sadikoglu and Zehir, 2010). There are also some companies that share 
and provide financial information to the entire organization. In empowered organization, this information is distributed and disseminated.

\section{v) Employee Empowerment (EE)}

Truly empowered employee teams can help those organizations improve customer satisfaction, increase employee productivity, increase quality and lower costs (Yang and Choi, 2009). Workers feel empowered when they are in an environment where their ideas are respected and they feel free to make suggestions without fear of ridicule by superiors or fellow workers (Gaudreau Meyerson, 2012). Implementing the principle of empowerment in stages fosters this type of environment and can increase employee productivity and input.

\section{vi) Human Resource Development (HRD)}

Human resources are uniquely significant to keep business success. Competitive advantages can be gained by the organization if the organization uses its people effectively and strategically, draws on their expertise and define the objective clearly. The organization can enhance the level of quality if the talents and abilities within the organization are utilized effectively (Crosby, 1979; Deming, 1986; Garvin, 1988). The organizations must develop the potential of their employee by providing a conducive work area and training for organizational growth (Zakuan et al., 2010).

\section{vii) Management Policies and Strategies (MPS)}

Businesses need to implement effective strategies to succeed. The important thing for a business owner to keep clear is that strategic management is a mind-set philosophy for doing business, but business policies are the specific method for running the organization on a day-to-day business. The organizations will be better equipped to meet their goals and objectives if the owner and managers adopt a clear TQM philosophy (Jeremy C Bradley, 2014). The organization who implements TQM philosophy must have a clear vision, mission, policies, strategy for improving quality and quality target for the short and long term business plan (Vanichchinchai, 2011). It also incorporates the combination of customer satisfaction and quality issues into strategic plans which give authorization to the organization to set understandable and clear priority, form or create target goals and allocate resources (Sadikoglu and Zehir, 2010).

\section{Employee Performance}

When discussing about internal marketing of the company, one of the most significant factors that need to be emphasized is the performance. To reach the highest level of performance is challenging and tough due to the more and more challenges faced. The performance is the indicator to ensure the continuous development and market standard and also requirements of innovation. Organizational efficiency depends on the employee performance (Gruman and Saks, 2011).
Job performance is a variable commonly researched in conjunction with job satisfaction and there are several literatures that put attention on job performance. Job performance is defined as the value an organization can expect from discrete behaviours performed by an employee over time (Motowidlo, 2003). High performing employees will result to high performing organization because they are interrelated to each other. However, if the employee has low performance, it will negatively impact the organization too. During the performance management process, employee efforts are managed based on measured performance outcomes. Therefore, the job performance needs to be considered to measure employee performance in this research.

\section{ii) Employee Satisfaction}

Employee satisfaction has a positive influence on business performance (Jun et al., 2006). Employee satisfaction is an emotional state resulting from experiences of work (Locke and Schweiger, 1979). He defined the concept of job satisfaction based on his argument which is the satisfaction is achieved when the employee realizes one's important job values provided these are congruent with or help to fulfil one's basic needs. He highlighted the conducive values that contributing to job satisfaction which are mentally challenging work, personal interest, work that is not too physically exhausting, pay for performance, working condition, high self-esteem and organizational support. Besides that, according to Luthans, (1989), there are three aspects in employee satisfaction which are emotional response to the work environment, the relationship between expectation and outcomes and satisfaction with pay. When employee satisfaction can be achieved, the employee loyalty level will also increase and reduce the turnover rate (Jun et al., 2006).

\section{PROPOSED THEORETICAL FRAMEWORK}

A theoretical framework guides the researcher to determine the result that will be measured and the statistical relationship that will be generated from this research. In other words, theoretical framework involves identifying the network of relationship among variables as shown in Figure 2 (on next page).

\section{i) Job Performance}




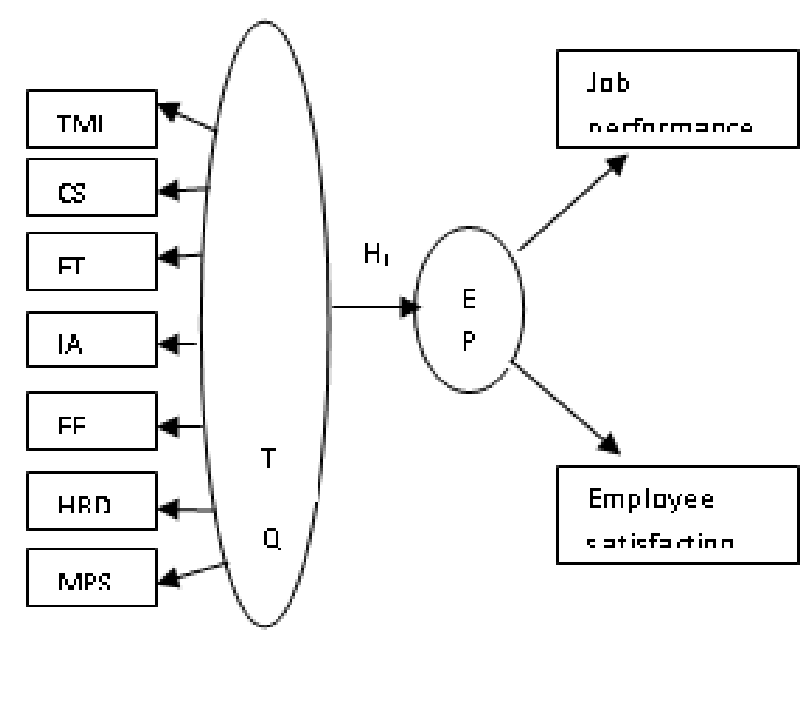

Fig. 2: A Proposed Theoretical Framework With Hypothesis Development

\section{HYPOTHESIS OF THE STUDY}

This study proposes a TQM performance model with moderator and mediator. From above research framework, review on the relationship between TQM practices and employee performance, and related hypothesis have been made based on literature review.

H1 : TQM practices are positively significance and direct effect on employee performance.

The researchers are highlighting the significance of the people component in the firm's reputation and performance (Bontis and Fitz-enz, 2002). According to Bontis and Fitzenz (2002) they found a strong positive correlation between human capital and business performance. It is clear to conclude that, employees are significantly vital asset to an organization (Kidd, 2006a). The author comes out with several manageable hypotheses. The employees will experience some positive impact on job satisfaction and organizational commitment if their organization implements TQM practices (Karia, 2003). According to Zakuan (2010) they had illustrates the importance of employees and the relationship to the organizational performance. Human factor is one of the determining variables besides environmental factors and organizational factors on the organizational culture, which will influence employee behaviours and organization performance (Kidd, 2006a). Therefore TQM practices will help to enhance the employee performance.

\section{V.CONCLUSION AND FUTURE RESEARCH}

The primary objective of this paper is to study the relationships between total quality management and their impact on employee performance in Malaysian manufacturing industry. Even though many studies have been performed to identify for successful implementation TQM practices, it is found that no previous study had tried to investigate the relationships between TQM practices and employee performance, especially in ASEAN countries. Thus, this research attempts to contribute to the development of quality management theory particularly in ASEAN countries.

To carry out this research, TQM constructs and employee performance measures have been investigated extensively as presented in the literature. Based on this review, a theoretical framework that links TQM constructs and employee performance measures which are employee satisfaction and job performance has been proposed. One hypotheses regarding the relation between the elements of the model were specified.

Next, the hypotheses regarding the relationships in the model will be tested on Malaysian manufacturing industry using the structural equation modeling technique. The results will explain the insignificant difference of TQM practices and the impact to employee performance in Malaysian manufacturing industry.

\section{ACKNOWLEDGMENT}

The authors wish to thanks the Malaysian Ministry of Education (MOE), Universiti Teknologi Malaysia (UTM) and Research Management Centre (RMC) for financial support to this work through grants funding number 4F864 and 14H10.

\section{REFERENCES}

[1] Agus, A. and Hassan, Z. (2011) Enhancing production performance and customer performance through Total Quality Management (TQM): Strategies for competitive advantage. Pp. 1650-1662 in: Procedia Social and Behavioral Sciences. https://doi.org/10.1016/j.sbspro.2011.09.019

[2] Ahmad, M.F. Bin and Yusof, S.M. (2010) Comparative study of TQM practices between Japanese and non-Japanese electrical and electronics companies in Malaysia: Survey results. Total Quality Management \& Business Excellence. . https://doi.org/10.1080/14783360903492520

[3] Black, S.A. and Porter, L.J. (1996) Identification of the Critical Factors of TQM. Decision Sciences, 27, 1-21. https://doi.org/10.1111/j.1540-5915.1996.tb00841.x

[4] Bontis, N. and Fitz-enz, J. (2002) Intellectual capital ROI: a causal map of human capital antecedents and consequents. Journal of Intellectual Capital.

https://doi.org/10.1108/14691930210435589

[5] Crosby, P.B. (1979) Quality is free: The art of making quality certain. in: McGrawHill. 309 pp.

[6] Deming, W.E. (1986) Out. Out of the Crisis.

[7] Flynn et al. (1994) A framework for quality management research and an associated measurement instrument. Journal of Operations Management. https://doi.org/10.1016/S0272-6963(97)90004-8 .

[8] Fotopoulos, C. V. and Psomas, E.L. (2010) The structural relationships between TQM factors and organizational performance. The TQM Journal. https://doi.org/10.1108/17542731011072874

[9] Gadenne, D. and Sharma, B. (2009) An investigation of the hard and soft quality management factors of Australian SMEs and their association with firm performance. International Journal of Quality \& Reliability Management, 26, 865-880. https://doi.org/10.1108/02656710910995064

[10] Garvin, A.G. (1988) No Title. Managing Quality, New York.

[11] Gaudreau Meyerson. (2012) Effects of Empowerment on Employees Performance. Advanced Research in Economic and Management Sciences (AREMS), 2. 
[12] Gruman, J.A. and Saks, A.M. (2011) Performance management and employee engagement. Human Resource Management Review, 21, 123 136. https://doi.org/10.1016/j.hrmr.2010.09.004

[13] Jeremy C Bradley, D.M. (2014) Strategic Management \& Business Policy | Chron.com. <http://smallbusiness.chron.com/strategicmanagement-business-policy-66066.html> (6 November 2014).

[14] Jun, M., Cai, S., and Shin, H. (2006) TQM practice in maquiladora: Antecedents of employee satisfaction and loyalty. Journal of Operations Management, 24, 791-812. https://doi.org/10.1016/j.jom.2005.09.006

[15] Karia, N. et al. (2003) TQM Practices: Continuous Improvement And Problem Prevention. International Business Information Management, 498-502.

[16] Kaynak, H. and Hartley, J.L. (2008) A replication and extension of quality management into the supply chain. Journal of Operations Management, 26, 468-489.

https://doi.org/10.1016/j.jom.2007.06.002

[17] Khanna, H.K., Sharma, D.D., and Laroiya, S.C. (2011) Identifying and ranking critical success factors for implementation of total quality management in the Indian manufacturing industry using TOPSIS. Asian Journal on Quality. .

[18] Kidd, C.A. (2006a) An exploration of the impact of employee job satisfaction, affect and performance on organizational financial performance in the health care industry.

[19] Koh, T.Y. and Low, S.P. (2010) Empiricist Framework for TQM Implementation in Construction Companies. Journal of Management in Engineering. . https://doi.org/10.1061/(ASCE)ME.1943-5479.0000014

[20] Locke, E.A. and Schweiger, D.M. (1979) Participation in decisionmaking: one more look. Research in Organizational Behavior, 1.

[21] Luthans, F. (1989) Organizational behavior (5th ed.). in: Organizational Behavior (5th Ed.)

[22] Meyer, S.M. and Collier, D.A. (2001) An emprical test of the causal relationships in the Baldrige Health Care Pilot Criteria. Journal of Operations Management, 19, 403-425. https://doi.org/10.1016/S0272-6963(01)00053-5

[23] Mohammad Talha. (2004) Total quality management (TQM): an overview. The Bottom Line, 17, 15-19. https://doi.org/10.1108/08880450410519656

[24] Motowidlo, S.J. (2003) Job performance. In W. C. Borman, D. R. Ilgen, R. J. Klimoski, \& Weiner, I. B. (Eds). Handbook of psychology, 39-53. https://doi.org/10.1002/0471264385.wei1203

[25] Phan, A.C., Abdallah, A.B., and Matsui, Y. (2011) Quality management practices and competitive performance: Empirical evidence from Japanese manufacturing companies. International Journal of Production Economics, 133, 518-529. https://doi.org/10.1016/j.ijpe.2011.01.024

[26] Prajogo, D., Chowdhury, M., Yeung, A.C.L., and Cheng, T.C.E. (2012) The relationship between supplier management and firms operational performance: A multi-dimensional perspective. International Journal of Production Economics, 136, 123-130. https://doi.org/10.1016/j.ijpe.2011.09.022

[27] Raj Kumar Dixit Garg T.K. Garg. (2011) TQM success factors in North Indian manufacturing and service industries. The TQM Journal, 23, 3646. https://doi.org/10.1108/17542731111097470

[28] Sadikoglu, E. and Zehir, C. (2010) Investigating the effects of innovation and employee performance on the relationship between total quality management practices and firm performance: An empirical study of Turkish firms. International Journal of Production Economics, 127, 13-26. https://doi.org/10.1016/j.ijpe.2010.02.013

[29] Valmohammadi, C. and Servati, A. (2011) Performance measurement system implementation using Balanced Scorecard and statistical methods. International Journal of Productivity and Performance Management. . https://doi.org/10.1108/17410401111140400

[30] Vanichchinchai, A. and Igel, B. (2011) The impact of total quality management on supply chain management and firm'... International Journal of Production Research, 49, p3405-3424.

https://doi.org/10.1080/00207543.2010.492805
[31] Wruck et al. (1998) The two key principles behind effective TQM programs. European Financial Management, 4, 401-23. https://doi.org/10.1111/1468-036X.00073

[32] Yang, S.-B. and Choi, S.O. (2009) Employee empowerment and team performance. Team Performance Management, 15, 289-301. https://doi.org/10.1108/13527590910983549

[33] Yusuf et. al. (2007) Implementation of TQM in China and Organisation Performance: An Emprical Investigation. Total Quality Management and Business Quality, 18, 509-530. https://doi.org/10.1080/14783360701239982

[34] Zadry, H.R., \& Yusof, S.M. (2007) Total quality management and theory of constraints implementation in Malaysian automotive suppliers. Total Quality Management, 17, 999-1020. https://doi.org/10.1080/14783360600747911

[35] Zakuan, N.M., Yusof, S.M., Laosirihongthong, T., and Shaharoun, A.M. (2010) Proposed relationship of TQM and organisational performance using structured equation modelling. Total Quality Management \& Business Excellence. . https://doi.org/10.1080/14783360903550020

[36] Zhang, Z. (2000) Implementation of Total Quality Management: an empirical study of Chinese manufacturing firms. 